ラットKupffer 細胞执よび肝類洞内皮細胞の細胞内遊離カルシウム イオン濃度に及ぼす epidermal growth factor（EGF）の影響

\author{
市川 裕三 溝口 靖紘 木田 徹 \\ 小林 絢三* 森沢 成司** 大倉 靖史***
}

要 旨：著者らは肝類洞壁細胞の一つである Kupffer 細胞の産生するサイトカインを epidermal growth factor (EGF) が増強することを認めた。そこで, EGF の肝類洞壁細胞に対する 作用機序を解明するため, Kupffer 細胞おょび肝類洞内皮細胞を用いて, 細胞内情報伝達機構の 面から，EGFの細胞内遊離カルシウムイオン $\left(\mathrm{Ca}^{++}\right)$濃度に及ぼす影響について検討した。そ の結果, EGF は Kupffer 細胞及び肝類洞内皮細胞の細胞内遊離 $\mathrm{Ca}^{++}$濃度を增加させた。既にサ イトカインの産生が細胞内遊離 $\mathrm{Ca}^{++}$介して増強することが報告されているので，EGF は肝 類洞壁細胞の細胞内遊離 $\mathrm{Ca}^{++}$を代てサイトカインの産生を増強することが示唆された。

索引用語： EGF Kupffer 細胞肝類洞内皮細胞 細胞内 $\mathrm{Ca}^{++}$

\section{緒言}

Epidermal growth factor (EGF) はマウスの䅡下 腺から発見された分子量約6000の酸性ペプチドで， ラットの四塩化炭素やD-galactosamineによる肝細 胞障害に扰いて肝細胞再生促進効果があることが報告 されている2,3). そのため, EGF の肝細胞再生を期待し て臨床的にも既に劇症肝炎に投与されている゙。ささ Kupffer 細胞は resident macrophage として種々のサ イトカインやケミカルメディメーターを産生し肝局所 に技ける病態形成や恒常性維持に重要な役割を演しる

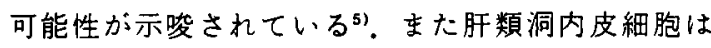
Kupffer 細胞，伊東細胞および pit 細胞とともに肝類 洞壁細胞を構成し， endotoxin 等により活性化され 様々な物質を放出する ソ1(IL1)を産生すること占、プロスタグランジン(PG) を産生することより》，免疫反応やフラキドンカス ケードの相互作用を調節して, 肝局所でのネットワー クに大きく関与している可能性が考えられている.

このよらな背景因子により，著者らは EGFの薬理 作用を検討するため肝類壁細胞の一つである Kupffer 細胞を用いてサイトカインの産生に及ぽす影響につい て検討した. その結果, EGF が Kupffer 細胞の産生す

* 大阪市立大学医学部第 3 内科

**同 第一生化学

****ムラ薬理研究所

〈受付日1991年10月 2 日 $>$
るIL1を増強することを認めた8)。そこで，著者らは EGF の Kupffer 細胞に及ぼす作用機序を解析するた め細胞内情報云達機構, 特に現在最も注目を浴びてい、 る細胞内 $\mathrm{Ca}^{++}$の面から検討した。

\section{実験方法}

\section{1. 材料}

ラットは Wistar 系雄性ラット（約200g）を用い日本 クレフ社から購入した. Pronase Eは Merck 社 (Darm stadt, F.R.G.) から, collagenase type IVは 和光純薬か. ら, HEPES (N-2.hydroxyethyl-N-2etanesulfonic acid) および metrizamide (2- [3acetamino-5-N-methyl-1-acetamido-2, 4, 6triiodobenzamido] -2-deoxy-D-glucose) は Sigma 社 (St. Louis, MO)から, EDTA (ethylene-diaminetetra acetic acid), disodium salt は和光純菜から購入した。 Fura 2-AM は同化化学より購入した。なお，EGFは 日立化成工業株式会社より供与された。

\section{2.ラット Kupffer 細胞の調㥿}

正常 Wistar 系雄性ラットの門脈にカテーテルを插 入し, $\mathrm{Can}^{++}$free HEPES 加 HBSS (Hanks' balanced salt solution) $100 \mathrm{~m} l$ を流した。続いて $0.05 \% \mathrm{col}$. lagenase および0.1\%pronase Eを含むHEPES 加 HBSS $100 \mathrm{~m} l$ を順次流した。灌流後, 肝荿を摘出し, $0.05 \%$ pronase E を含んた HEPES 加 HBSS $100 \mathrm{~m} l$ 中で $37^{\circ} \mathrm{C} ， 20$ 分間振盪培養し，消化した。そ後，得 られた細胞浮遊液を遠心 $(400 \times \mathrm{g}, 10 \mathrm{~min}) 2$ 回洗浄後, 
その cell pellet $5 \mathrm{~m} l$ の HBSSに浮避させ $30 \%$ metrizamide 容液 $7 \mathrm{~m} l$ と混合乙重層遠心 $(1,400 \times \mathrm{g}$, $10 \mathrm{~min}$ )した，最上相の肝非実質細胞相をとり，洗浄後 $20 \%$ fetal calf serum (FCS) 含有 RPMI 1640に浮遊 させ,ブラスチックシャーレ(Falcon 3003)に注入し， $37^{\circ} \mathrm{C} て ゙ 24$ 時間培養した。プラスチックシャーレに付着 した細胞を Kupffer 細胞とし， $5 \%$ FCS を含む RPMI 1640 に浮遊させて, $2 \times 10^{6} \mathrm{cells} / \mathrm{m} l$ に調整して串験 に供した。

\section{3.ラット肝類洞内皮細胞の調製}

前述の肝非実質細胞相をとり，洗浄後 HBSS 溶液で $1 \times 10^{8} \mathrm{cells} / 100 \mathrm{~m} l$ に調製した。この細胞浮遊液から Knook らクの方法に準じて，SRR6Y 型エルトリェー タロータ（日立工機製）を用いて肝類洞内皮細胞を分 離した。なお，この方法を用いると95\%以上の肝類洞 内皮細胞が摂取できた。

\section{4. 細胞内遊離 $\mathrm{Ca}^{++}$濃度の測定方法}

前述の Kupffer 細胞あるいは肝類洞内皮細胞浮遊 液をFCSで処理したカ・゙ーガラス（厚さ0.12〜0.17 $\mathrm{mm})$ を入机たプラスチックシャーレに添付して24時 間培盖した。培盖後，1\%bovine serum albumin を含 む HEPES 加 HBSS にて洗浄後, Fura 2-AM $2 \mu \mathrm{M}$ を 含む同溶液を添加し， $37^{\circ} \mathrm{C} て ゙ 20$ 分間培養した。この細 胞の励起波長 $340 \mathrm{~nm}$ およひ $360 \mathrm{~nm}$, 蛍光波長 $540 \mathrm{~nm} に$ おける蛍光強度を倒立型営光顕微鏡 (ニコン)を用い て高感度 SIT カィラ（三菱化成，SITC 2400-08）にて 測定した. 虽光強度変化の測定ならびに測定画像の画 像処理は Argus $100 \mathrm{CA}$ 画像処理システム（浜松ホ卜 ニクスうにより行った。また，細胞内遊離 $\mathrm{Ca}^{++}$濃度は 別に作成した検量線より算出し，EGFで刺激した場合 の Kupffer 細胞遊離 $\mathrm{Ca}^{++}$濃度の変化を測定した。

\section{5. 統計学的検討}

すべて実験結果はMean \pm SEであらわし，有意差検 定はStudent's t test で検定を行った。

\section{実験結果}

\section{EGF 刺激によるKupffer 細胞の細胞内遊離} $\mathrm{Ca}^{++}$湿度の变動

上述の方法にて分離した Kupffer 細胞浮遊液に Fura 2-AMを取り込ませた後, 種々の濃度の EGFで 細胞を刺激して, 経時的に細胞内遊離 $\mathrm{Ca}^{++}$濃度を測定 した。 その結果, EGF 添加前の Kupffer 細胞の細胞内

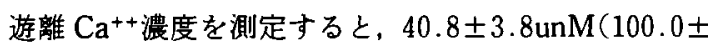

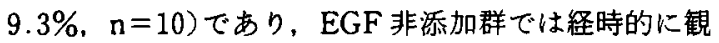
察したがほとんど変化がなかった。しいし EGF 添加

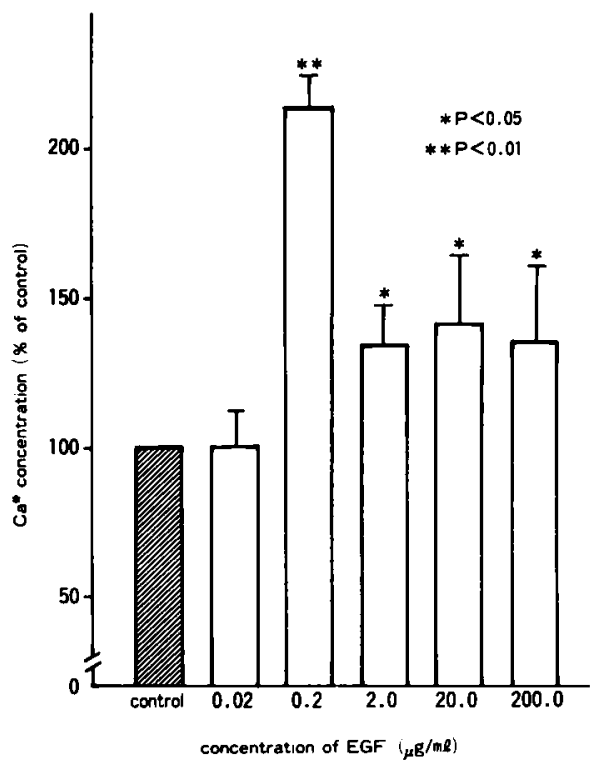

Fig. 1 Effects of EGF on intracellular $\mathrm{Ca}^{++}$concentration in Kupffer cells

群では細胞内遊離 $\mathrm{Ca}^{++}$濃度が徐々に上昇し $\mathrm{EGF}$ 添 加後10分で最高値を示した。すすなわち，EGFを0.02 $\mu \mathrm{g} / \mathrm{ml}, 0.2 \mu \mathrm{g} / \mathrm{m} l, 2.0 \mu \mathrm{g} / \mathrm{m} l, 20.0 \mu \mathrm{g} / \mathrm{m} l$ および200 $\mu \mathrm{g} / \mathrm{m} l$ を派加すると，10分後には，それぞれ100.8土 $10.8 \%(\mathrm{n}=10), 212.1 \pm 12.5 \%(\mathrm{p}<0.01, \mathrm{n}=10)$, $134.3 \pm 14.5 \%(\mathrm{p}<0.05, \mathrm{n}=10), 141.3 \pm 21.6 \%(\mathrm{p}<$ $0.05, \mathrm{n}=10), 135.2 \pm 24.1 \%(\mathrm{p}<0.05, \mathrm{n}=19)$ となっ た (Fig. 1).

2. EGF 刺激による肝類洞内皮細胞の細胞内遊離 $\mathrm{Ca}^{++}$濃度に及ほす影響

肝類洞内皮細胞浮遊液にFura 2-AMをとりこま せ, その後に各種の濃度の $\mathrm{EGF}$ を添加して, 経時的に 細胞内遊離 $\mathrm{Ca}^{++}$裖度を測定した。 その結果, $\mathrm{EGF}$ 非添 加前の肝類洞内皮細胞の細胞内遊離 $\mathrm{Ca}^{++}$濃度 は $42.1 \pm 5.0 \mathrm{nM}(100.0 \pm 11.5 \%, \mathrm{n}=10)$ であった。 た, $\mathrm{EGF}$ 添加では細胞内遊離 $\mathrm{Ca}^{++}$濃度は变化がな かったが, $\mathrm{EGF}$ 添加群では10分後に細胞内遊離 $\mathrm{Ca}^{++}$ 濃度は最高値を示した。すなわち，EGF の濃度が0.02 $\mu \mathrm{g} / \mathrm{m} l, 0.2 \mu \mathrm{g} / \mathrm{m} l, 2.0 \mu \mathrm{g} / \mathrm{m} l, 20.0 \mu \mathrm{g} / \mathrm{m} l, 200.0 \mu \mathrm{g} /$ $\mathrm{m} l$ の時に細胞内遊離 $\mathrm{Ca}^{++}$濃度は103.4 $11.2 \%(\mathrm{n}=$ $10), 212.6 \pm 28.8 \%(\mathrm{p}<0.01, \mathrm{n}=10), 186.2 \pm 21.2 \%$ $(\mathrm{p}<0.01, \mathrm{n}=10)$ であった(Fig. 2).すなわち，肝類 洞内皮細胞の場合孔 Kupffer 細胞と同様に $0.2 \mu \mathrm{g} / \mathrm{m} l$ の $\mathrm{EGF}$ の刺激により細胞内遊離 $\mathrm{Ca}^{++}$濃度は著明に 


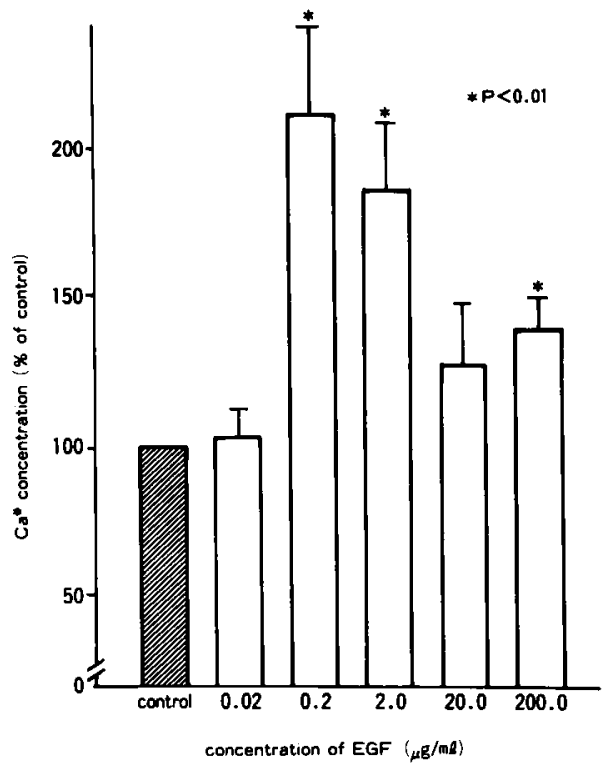

Fig. 2 Effects of EGF on intracellular $\mathrm{Ca}^{++}$concentration in hepatic sinusolidal endotherial cells

上昇した。

\section{考 察}

肝類洞壁細胞は Kupffer 細胞, 伊東細胞, 肝類洞内 皮細胞および pit 細胞からなり、肝類洞壁を構成し，他 の細胞とは形態学的, 細胞化学的さらには生化学的な 面などから区別されている。その中で, Kupffer 細胞お よび肝類洞内皮細胞は活性化されると，様々な物質を 産生する。その中にはILlがありの)これらの細胞が肝 局所の免疫反応に一定の役割を果たすと同時に, PG を産生することにより》, フラキドン酸カスケードに む関与すると考它られる。従って，PGに代表されるて ラキドン酸カスケートとILIに代表される免疫反応の 相互作用を明らかにすることは，肝局所の免度反応， 炎症反心を考える5えで重要なポイントであり，同時 に，Kupffer 細胞扰よび肝類洞内皮細胞を含めた肝類 洞壁細胞の肝局所反応を理解することは大きな課題で ある。

以上のような観点から著者らは肝疾患に対する治療 薬がどの様な影響を及洔すかについて検討している。

さて, EGF は肝細胞再生促進効果より劇症肝炎の治 療に用いられている゙1. また, EGF の薬理作用としては 細胞周期において $\mathrm{G}_{0}$ から early $\mathrm{G}_{1}$ 期に働声，protein kinase を活性化するとともにDNA 合成を促進し，細 胞増殖作用をしめす间。さらに，著者らは EGFが
Kupffer 細胞からのサイトカインの産生を高めること を認めだ!。しかし，EGFがどの様な機序でこれらの細 胞のサイトカインの産生に影響を及ぼすかについては 不明である。そこで今回著者らは，EGF の肝局所の細 胞に及ぼす影響を細胞内のレベルで検討する端緒とし て, EGF 刺激による Kupffer 細胞及び肝類洞内皮細胞 の細胞内 $\mathrm{Ca}^{++}$濃度に及ぼす影響について検討した。 の結果, EGF は Kupffer 細胞および肝類洞内皮細胞の 細胞内遊離 $\mathrm{Ca}^{++}$濃度を有意に上昇することが明らか となった。細胞内遊離 $\mathrm{Ca}^{++}$濃度の上昇は既にサイトカ インの産生に関与することが報告されているので11， 今回の実験結果から EGF は肝類洞壁細胞の細胞内 $\mathrm{Ca}^{++}$濃度を介してサイトカインの産生に関与してい ると考えられる，また，細胞内遊離 $\mathrm{Ca}^{++}$濃度は phos-

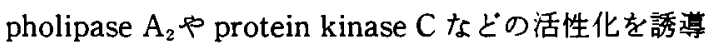
し，細胞内反応系のカスケートに拈ける初期段階にお いて非常に重要な役割を演しることが示されてい $ろ^{12}$.さらに, 細胞内遊離 $\mathrm{Ca}^{++}$濃度の上昇は microfilament の收縮を誘導し細胞形態にも影響を及ぼす ことが示唆されている ${ }^{13}$. 従って, 肝類洞壁細胞の機能 に細胞内遊離 $\mathrm{Ca}^{++}$が重要な役割を演じていると同時 に, $\mathrm{EGF}$ は細胞内遊離 $\mathrm{Ca}^{++}$の濃度を介して肝類洞壁 細胞に影響を及ぼすことが示唆された. EGFの細胞内 遊離 $\mathrm{Ca}^{++}$濃度の上昇機序については今回明らかでは ないが, 著者らは先に EGFが Propionibacterium acnes および lipopolysaccharide を用いる急性肝不全 モデルにおいて EGF が生存率を著明に改善するとと もに，肝組織をも著明に改善した。すなわち，著者ら はEGF が肝細胞膜の保護作用を有することを認めて おり, 今回, 観察された細胞内遊離 $\mathrm{Ca}^{++}$濃度の上昇作 用に関しても，EGF が細胞膜に対して何らかの作用を 有する可能性が示㖫される。いずれにせよ，EGFが Kupffer 細胞おょび肝類洞内皮細胞の細胞内遊離

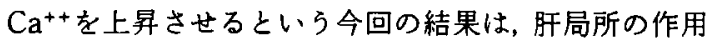
機序を解析する上に肝類洞壁細胞の細胞内遊離 $\mathrm{Ca}^{++}$ 濃度の検討が重要であることを示嘫した。

$$
\text { 文献 }
$$

1) Cohen $S$ : Isolation of mouse submaxillary gland protein accelerating incisoreruption and eyelid opening in the new born animal. J Biol Chem 237: 1555-1562, 1962

2）村上不二男：急性肝障害における epidermal growth factorkよる肝再生促進効果についての

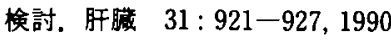


3）片山 宏, 杉山 貝, 山本俊郎, 他：実験肝不全に おりる EGFの効果. Therapeutic Reserch 10: 1988-1993, 1989

4）沖田極, 白沢宏幸, 山下智省, 他：EGF 療法の 開発に関する検討. 厚生省難治性の肝炎研究班, 劇 症肝炎分科会, 1989年報告集, p103-109

5）溝口靖紘：肝アラキドン酸代謝とその生理学的意 義. 現代医療 $23: 655-708,1991$

6) Mizoguchi $Y$, Kawada N, Ichikawa $Y$, et al: Effect of Shou-saiko-to on interleukin 1 production by hepatic sinusoidal endothelial cells. J Med Pharm Soc WAKAN-YAKU $6: 172-176$, 1989

7) Shaw RG, Johnson AR, Schulz WW, et al: Sinusoidal endothelial cells from normal guinea pig liver: Isolation, culture and characterization. Hepatology 4:591-602, 1984

8）木田徹, 溝口靖紘, 市川裕三, 他：Epidermal growth factor (EGF) の実験的急性肝不全モデル およびKupffer 細胞に及ぼす影響，日消誌 投稿 中
9) Knook DL, Sleyster ECH : Separation of Kupffer and endothelial cells of the rat liver by centrifugal elutriation. Exp Cell Res 99: 444 $-449,1976$

10) Raper S, Burwen SJ, Barker ME, et al : Translocation of epidermal growth factor to the hepatocyte nucleus during rat liver regeneration. Gastroenterology 92 : 1243-1250, 1987

11) Mahe $Y$, Wakasugi $H$, Scamps $C$, et al: Role of calcium on interleukin-1 production by monocytes its relevance during $\mathrm{T}$ cell proliferation. Lymphokine Cytokine Res 10: 165-172, 1991

12) Pickett WC, Jesse RL, Cohen $P$ : Initiation of phospholipase A2 activity in human platelet by the calcium ionophore A23187. Biochem Biophys Acta 486 : 209-213, 1977

13) Kakiuchi S, Sobue K : Control of cytoskelton by calmodulin and calmodulin-binding protein. TIBS $8: 59-63,1983$

\title{
Effect of epidermal growth factor (EGF) on cellular Ca concentration in Kupffer cells and hepatic sinusoidal endotherial cells
}

\author{
Yuzo IchIKawa, Yasuhiro Mizoguchi, Toru KiDA, Kenzo KoBaYASHI*, \\ Seiji MORISAWA** and Yasuhiro OKURA***
}

We examined the effects of epidermal growth factor (EGF) on cellular $\mathrm{Ca}^{++}$concentration in Kupffer cells and hepatic sinusoidal endothelial cells. As results, EGF increased intracellular $\mathrm{Ca}^{++}$ concentration in Kupffer cells and hepatic sinusoidal endothelial cells. These results suggest that EGF may affect the function of hepatic sinusoidal cells by the control of intracellular $\mathrm{Ca}^{++}$concentration.

* The Third Department of Internal Medicine, Osaka City University Medical School (Osaka)

** The First Department of Biochemistry, Osaka City University Medical School (Osaka)

*** Tsumura Research Institute for Pharmacology 